\title{
シリコン表面の窒化初期過程とエネルギーバンドギャップの形成
}

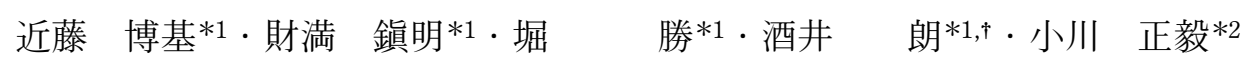

\section{Initial Stage of Processes and Energy Bandgap Formation in Nitridation of Silicon Surface Using Nitrogen Radicals}

\author{
Hiroki KONDO*1, Shigeaki ZAIMA*1, Akira SAKAI*1,^ and Masaki OGAWA*2 \\ ${ }^{* 1}$ Graduate School of Engineering, Nagoya University, Furo-cho, Chikusa-ku, Nagoya, 464-8603 Aichi \\ ${ }^{* 2}$ EcoTopia science institute, Nagoya University, Furo-cho, Chikusa-ku, Nagoya, 464-8603 Aichi \\ ${ }^{\dagger}$ Present affiliation: Department of Systems Innovation, Graduate School of Engineering Science, Osaka University, \\ Machikaneyama-cho, Toyonaka, 560-8531 Osaka
}

(Received June 15, 2007, Accepted October 13, 2007)

\begin{abstract}
Initial stage of processes and energy bandgap formation in nitridation of silicon surfaces using nitrogen radicals have been studied. According to scanning tunneling microscopy observations and scanning tunneling spectroscopy measurements, at the initial stage of nitridation, linear defects perpendicular to dimmer rows were formed to coincide with an initial nitridation reaction preferentially at backbonds of surface Si atoms. After the nitride formation, the surface roughness depends only on substrate temperature regardless of radio frequency $(\mathrm{RF})$ power, which means that the growth mode of nitrides is attributed to the surface migration. Contrary, the energy bandgap of silicon nitrides is significantly affected by not only substrate temperature but also RF power. Absorption and emission spectroscopy results suggest that the contribution of the excited-state nitrogen atoms to the nitridation increases with increasing the $\mathrm{RF}$ power. Control of surface migration and radical species is crucial to form the monolayer-thick nitride layer with both an atomically flat surface and a wide energy bandgap.
\end{abstract}

\section{1. はじめに}

超々大規模集積回路（ULSI）の研究開発においては，金 属-酸化膜-半導体（MOS）トランジスタのゲート絶縁膜と して, シリコン酸化膜 $\left(\mathrm{SiO}_{2}\right)$ 換算で $1 \mathrm{~nm}$ 以下の膜厚が要 求されている. 物理膜厚 $1 \mathrm{~nm}$ の $\mathrm{SiO}_{2}$ ではトンネルリーク 電流や pMOSにおけるB 拡散を抑制することができないた め, $\mathrm{SiO}_{2}$ に比べて誘電率が高く, $\mathrm{B}$ 拡散に対するバリア効 果の高いシリコン酸窒化 $(\mathrm{SiON})$ 膜が必須となっている ${ }^{1-3)}$.

しかし, 窒素濃度の増大に伴って閾值電圧のシフトや移動度 の低下が生じるため, $\mathrm{SiON}$ 膜中の窒素プロファイル制御が 重要な課題である4-7). SiON 膜の作製方法としては, 熱酸 化で形成した $\mathrm{SiO}_{2}$ 膜をアンモニア $\left(\mathrm{NH}_{3}\right)$, 一酸化窒素 $(\mathrm{NO})$, 亜酸化窒素 $\left(\mathrm{N}_{2} \mathrm{O}\right)$ または窒素プラズマで後窒化す る方法や, $\mathrm{NO}$ または $\mathrm{N}_{2} \mathrm{O}$ で $\mathrm{Si}$ 表面を直接, 酸窒化する方 法がある ${ }^{4,6-13)} . \mathrm{SiO}_{2}$ 膜を窒化する場合において，プラズマ 窒化を用いる方法は熱窒化法に比較して低温で窒化可能であ り, 窒素プロファイルの制御も容易で, 膜表面にの久高濃度 の窒素を導入できる。 また最近では, 先にプラズマ窒化した シリコン $(\mathrm{Si})$ 表面を後酸化することでサブナノメートルの $\mathrm{SiON}$ 膜を作製する手法も提案されている14). 同手法のメ力 ニズムは未だ不明確であるが，このように現在の ULSI 作製 プロセスにおいて，ゲート $\mathrm{SiON}$ 膜形成のためのプラズマ窒 化処理は極めて重要な技術となっている．また同時に，その

*1 名古屋大学大学院工学研究科（干464-8603 愛知県名古屋市千 種区不老町)

*2 名古屋大学エコトピア科学研究所 ( 市千種区不老町)

+ 現所属: 大阪大学大学院基礎工学研究科 (T560-8531 大阪府 豊中市待兼山町 1-3)
ような極薄 $\mathrm{SiON}$ 膜を形成するには，窒素プラズマを用いた シリコン基板表面の窒化初期過程ならびに窒化機構の理解を 欠くことができない.

現在の ULSI 作製プロセスでは, プラズマ窒化以外にも, ドライエッチングやプラズマ励起化学気相蒸着 (PE-CVD) 法など，様々なプラズマプロセスが用いられている. しかし ながら，一般にそれらの機構は十分に解明されては抢らず, 経験則に頼らざるを得ない傾向がある．これは，プラズマプ ロセスが複数の活性種が関与する複雑な過程であること, ま たその分析手法が限られることなどによる、本稿ではまず初 めに, 本研究で用いた窒素プラズマ中の活性種について, そ の分析手法と併せて説明する. その後, $\mathrm{Si}(001)$ 清浄表面の ラジカル窒化プロセスに抢ける窒化初期過程と, シリコン窒 化膜におけるエネルギーバンドギャップ形成過程について述 ベる.

\section{2. 窒素プラズマ分析 ${ }^{15)}$}

Fig. 1 は, 本研究で用いた誘導結合型プラズマ (ICP) 源 の模式図である.コイルに高周波 (RF) 電力を投入するこ とで反応管内に導入した $\mathrm{N}_{2}$ ガスを励起し, 窒素プラズマを 形成する. 本実験では, 周波数 $13.56 \mathrm{MHz}, 100-300 \mathrm{~W}$ の

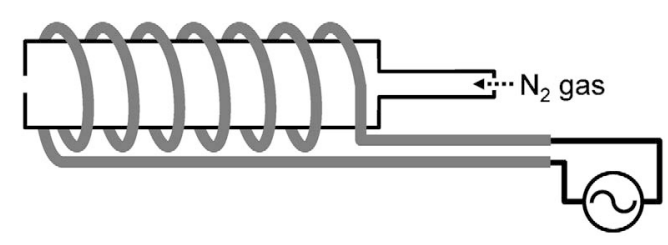

Fig. 1 Schematic illustration of inductively-coupled plasma (ICP) source. 
$\mathrm{RF}$ 電力を用いた. 容量結合型プラズマ $(\mathrm{CCP})$ ではプラズ マ中の電子のエネルギーは大きいが, 電子密度が低いのに対 し, ICP 中では相対的に電子のエネルギーは小さいが密度が 大きいという特徵がある.このため, ICP 源を用いることで $10^{-3}-10^{-2} \mathrm{~Pa}$ 程度の低窒素分圧においても高密度な窒素ラ ジカルを形成できる. 一般に, 窒素プラズマ中には, 基底状 態の原子状窒素 $(\mathrm{N})$, 励起状態の原子状窒素 $\left(\mathrm{N}^{*}\right)$, 励起 状態の分子状窒素 $\left(\mathrm{N}_{2}^{*}\right)$ および窒素分子イオン $\left(\mathrm{N}_{2}^{+}\right)$が存 在して抢り，それらは発光分光法 (OES) により確認する ことが出来る.

Fig. 2 は, $\mathrm{N}_{2}$ ガス分圧 $2.7 \times 10^{-3} \mathrm{~Pa}, \mathrm{RF}$ 電力 $100 \mathrm{~W}$ およ び300 W で形成した ICP からの発光スペクトルである. 図 中に主な発光種のエネルギー状態間遷移を示しており, $\mathrm{N}^{*}$, $\mathrm{N}_{2}^{*}$ および $\mathrm{N}_{2}^{+}$の存在を確認することが出来る. 個々のスぺ クトルの強度は, 対応する遷移過程の初期状態の窒素ラジカ ルまたはイオンの密度に比例している. したがって, 異なる プラズマ生成条件（ $\mathrm{N}_{2}$ ガス分圧, $\mathrm{RF}$ 電力など）に対して, 個々のスペクトル強度の変化を調べることで, 対応する活性 種の密度変化を知ることが出来る。但し，エネルギ一準位間 の遷移確率は個々に異なるため, 異なる波長のスペクトル間 の強度比較から対応する励起種の密度差を論じることは出来 ない. また, 基底状態よりも低いエネルギー状態は存在しな いため, 発光スペクトルから $\mathrm{N}$ の密度を知ることは出来な w.

Fig. 2 に打いて, RF 電力 $300 \mathrm{~W}$ の場合では, 波長745や $867 \mathrm{~nm}$ などに N*に起因する鋭いスペクトルが観測される のに対して, $\mathrm{RF}$ 電力 $100 \mathrm{~W}$ の場合ではこれらのスペクトル はほとんど観測されない。したがって，高 RF 電力において N*が生成されることがわかる．Fig. 3 は $\mathrm{N}^{*}$ および $\mathrm{N}_{2}^{*}$ から の波長 745 抢よび $294 \mathrm{~nm}$ のスペクトル強度の RF 電力依存 性である. N*に対応するスペクトル強度が, RF 電力に対し てほぼ線形に増大するのに対し， $\mathrm{N}_{2}^{*} に$ 対応するスペクトル 強度は飽和傾向となっている，これらは，ICP 中の $\mathrm{N}^{*} の$ 密 度は $\mathrm{RF}$ 電力に伴って線形に増加するが， $\mathrm{N}_{2}^{*}$ の密度は飽和 傾向であることを示唆している.

基底状態にある原子状窒素 $\mathrm{N}$ の絶対密度は, 真空紫外吸 收分光法（Vacuum ultraviolet absorption spectroscopy）に

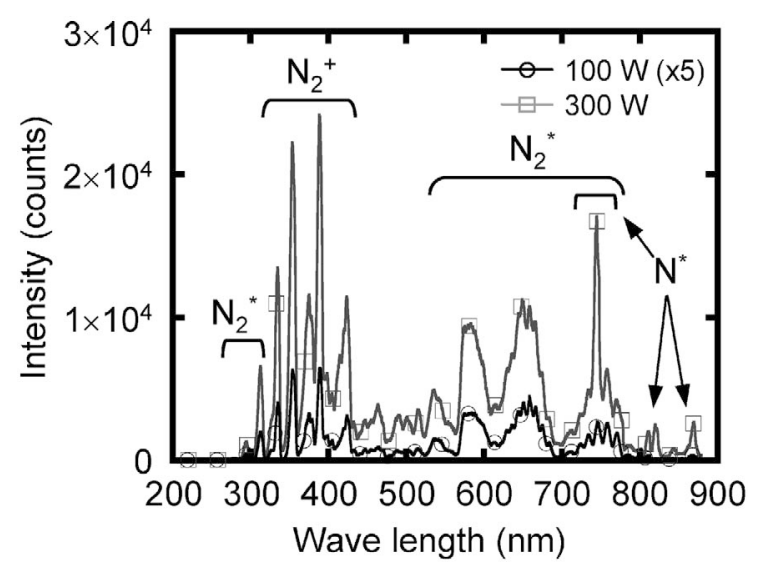

Fig. 2 Optical emission spectra of nitrogen plasma generated by ICP source.
よって求めることが出来る. Fig. 4 は, 本研究で用いた VUVAS 測定系の模式図である16). 本システムでは, マイク ロホローカソードで生成した窒素プラズマを光源として用 い, 測定対象である窒素プラズマでの吸収率からラジカル密 度を求める. まず，マイクロホローカソードからの発光のう ち, 波長 $120 \mathrm{~nm}$ のスペクトル強度を対向する分光器を用い て計測する. この遷移スペクトルは, 原子状窒素の第一励起 状態から基底状態への遷移である, $2 p^{2} 3 s^{4} P_{5 / 2} \rightarrow 2 p^{34} S_{3 / 2}^{\circ}$ $(119.995 \mathrm{~nm}), 2 p^{2} 3 s^{4} P_{3 / 2} \rightarrow 2 p^{34} S_{3 / 2}^{\circ} \quad(120.022 \mathrm{~nm})$ および $2 p^{2} 3 s^{4} P_{1 / 2} \rightarrow 2 p^{3} 4 S_{3 / 2}^{\circ} \quad(120.071 \mathrm{~nm})$ に対応する. 次に, 窒 素プラズマを生成し, プラズマ中を通過することで減衰した スペクトルの強度を計測する. 波長 $120 \mathrm{~nm}$ のスペクトル光 の吸收率は, 窒素プラズマ中の $\mathrm{N}$ の密度に比例することか ら, Nの絶対密度を求めることが出来る. Fig. 5 は, VUVASにより計測した, ICP プラズマにおけるNの絶対 密度である. $\mathrm{N}$ の絶対密度は, $\mathrm{RF}$ 電力 $250 \mathrm{~W}$ までは $\mathrm{RF}$ 電 力の増加に伴って増加するが, $\mathrm{RF}$ 電力 $250 \mathrm{~W}$ から $300 \mathrm{~W}$ の 範囲では飽和することがわかる. 一方，イオンに関しては, 基板位置でのイオン電流を測定することにより, 基板に対す るフラックスを求めることが出来る.

以上のように, 発光および吸収分光やイオン電流計測を用 いることにより, 窒素プラズマ内のラジカルやイオンの密度

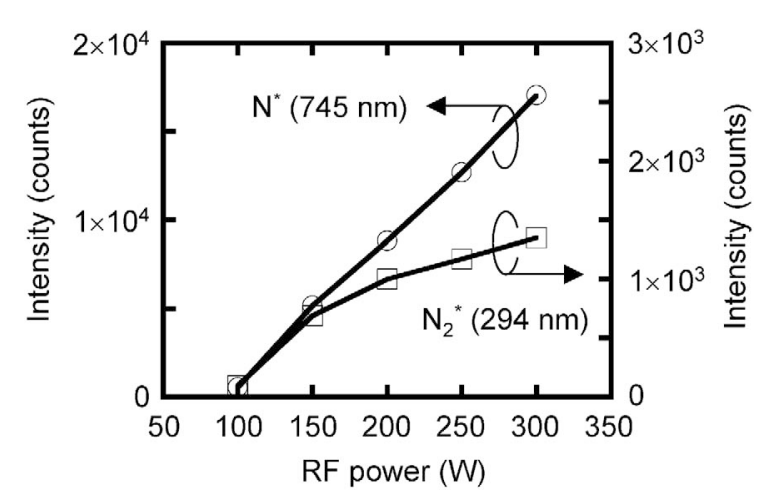

Fig. 3 RF power dependence of emission intensities of $\mathrm{N}^{*}$ and $\mathrm{N}_{2}^{*}$ peaks observed at 745 and $294 \mathrm{~nm}$, respectively.

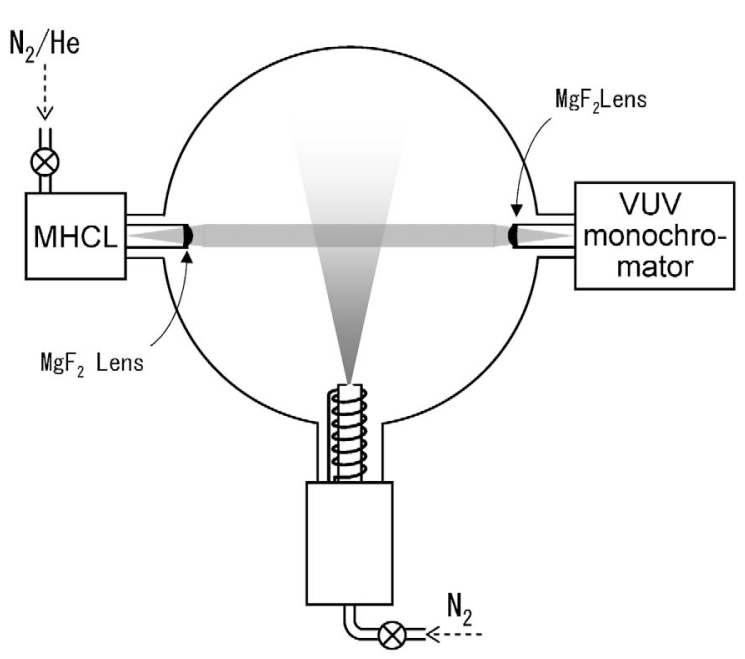

Fig. 4 Schematic illustration of vacuum-ultraviolet absorption spectroscopy (VUVAS) measurement system. 
変化を知ることが出来る.

\section{3. シリコン表面の窒化初期過程 ${ }^{17-19)}$}

Fig. 6 は, $\mathrm{Si}(001)-2 \times 1$ 清浄表面および $1 \mathrm{~L}$ の窒素ラジ カルに暴露した $\mathrm{Si}$ 表面の STM 像である. 窒化時の基板温 度は $800^{\circ} \mathrm{C}$ ，また STM 観察時の試料バイアスは（a）打よび (b) +2.0, (c) $-2.0 \mathrm{~V}$ である. 窒素ラジカル暴露後の $\mathrm{Si}$ (001) 表面には, 特徴的な 3 つの構造（図中 $\mathrm{P}, \mathrm{Q}$ 抢よび $\mathrm{R}$ ) が観測される。領域Pにおいて，非占有状態（b）では明る い輝点として観測されている部分が占有状態（c）では暗く 観測されている。これは， $\mathrm{Si}(001)$ 表面の特徵的な表面欠陥 構造の 1 つとして知られている C 型欠陥である. C 型欠陥 に対しては幾つかの構造モデルが提唱されているが，その 1 つとしてはダイマー間の表面第 2 層原子が 1 個欠損した構 造と考えられている20). Fig. 7 に $\mathrm{Si}(001)-2 \times 1$ 表面の再配 列構造と欠陥構造の模式図を示す21,22)。一方, 領域 Q で は, ダイマー列と垂直な方向に，直線的な欠陥が観測され る. 占有状態, 非占有状態共に暗い領域として観察されてお り, A 欠陥が直線的に並んだダイマー欠損列と考えられる. Fig. 6(b) の領域 R には, ダイマー列と垂直な方向に暗い線 が 2 本並んだ構造が存在して抢り, 占有状態（Fig. 6(c) ) ではこの部分は一様に暗い領域として観察されている.

Fig. 8 は $\mathrm{Si}(001)$ 清浄表面打よび Fig. 6 の領域 Q 打よび Rに抢けるSTS スペクトルである. 綎軸は規格化された微 分コンダクタンスであり, 観察試料表面の局所状態密度を反

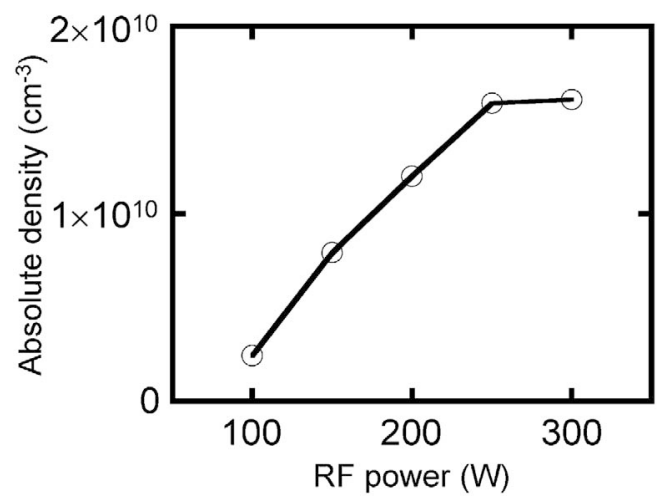

Fig. 5 RF power dependence of absolute density of groundstate nitrogen atoms.
映している23)．横軸は試料に印加した電圧をエネルギーと して表しており, 原点はフェルミエネルギー（ $\left.\mathrm{E}_{\mathrm{F}}\right)$ に対応 している. また負抢よび正のエネルギーはそれぞれ, 占有状 態と非占有状態を示している. Si (001) 清浄表面の STS スペ クトルでは， -0.7 および $+0.3 \mathrm{eV}$ 付近にそれぞれ $\pi_{\mathrm{d}}$ 結合状 態抢よび $\pi$ 米反結合状態に起因するピークが存在する。 ま

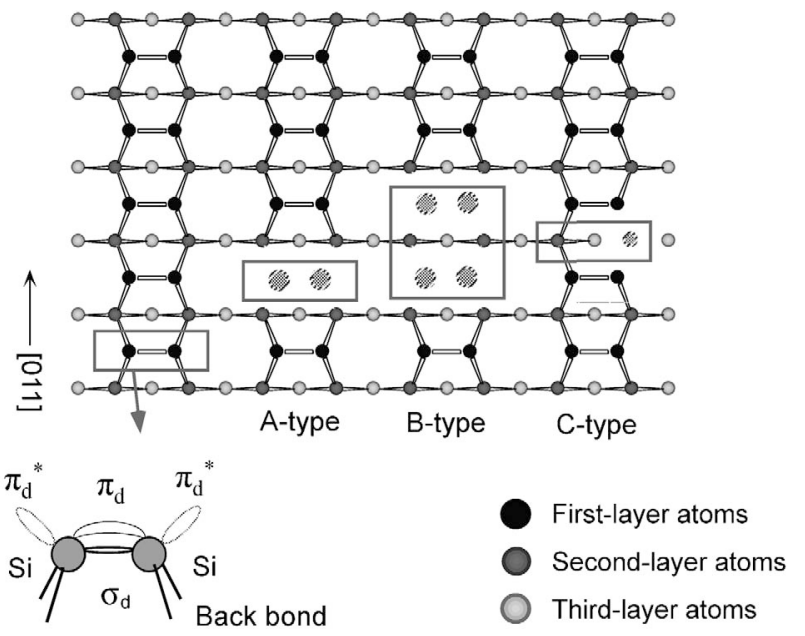

Fig. 7 Systematic diagram of clean $\operatorname{Si}(001)-2 \times 1$ surface.

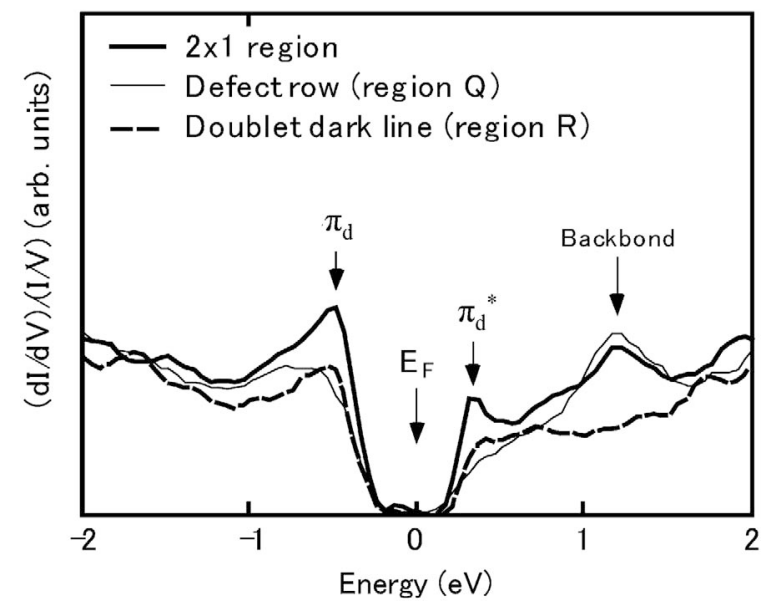

Fig. 8 STS spectra obtained from the $\mathrm{Si}(001)$ surface exposed to $1 \mathrm{~L}$ nitrogen radicals at $800^{\circ} \mathrm{C}$.
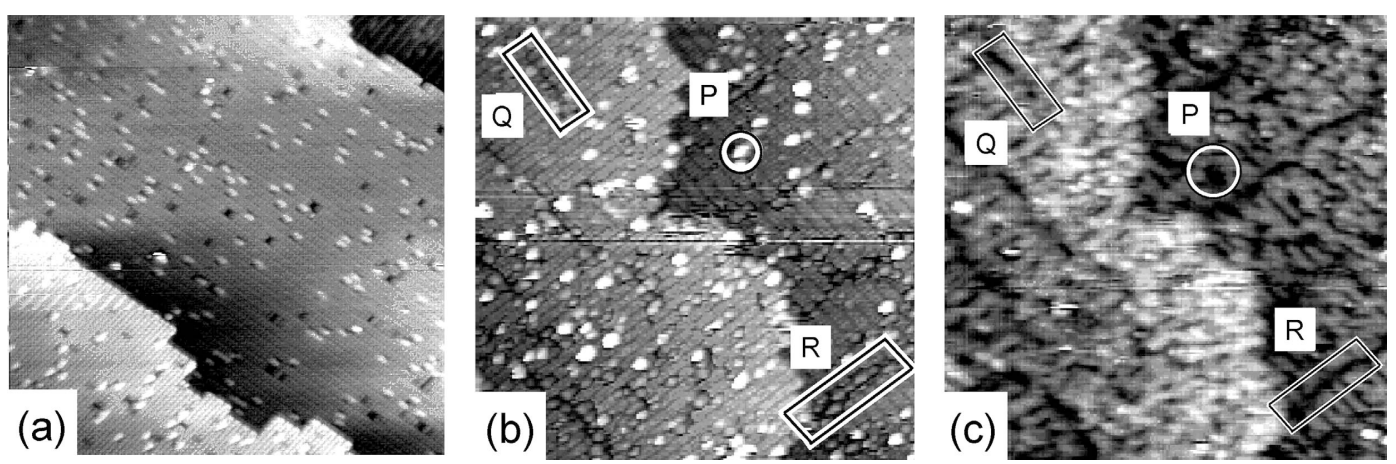

Fig. 6 STM images of (a) clean $\mathrm{Si}(001)-2 \times 1$ surface and (b), (c) $\mathrm{Si}(001)$ surface after exposure to $1 \mathrm{~L}$ nitrogen radicals at $800^{\circ} \mathrm{C}$. Sample biases were (a), (b) +2.0 and (c) $-2.0 \mathrm{~V}$, respectively. Observation areas were $50 \times 50 \mathrm{~nm}^{2}$. 
た， $+1.2 \mathrm{eV}$ 付近にはバックボンドの反結合状態に起因す

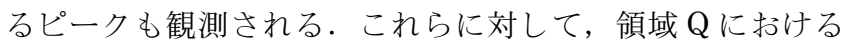
STS スペクトルでは， $\pi_{\mathrm{d}}$ 結合状態および $\pi_{\mathrm{d}}^{*}$ 反結合状態に起 因するピークが減衰しているが，バックボンドに起因する ピークは顕著に確認できる．したがって，このことからも領 域 $\mathrm{Q}$ はダイマー欠損列であることが結論できる. 一方, 領 域 R に拈ける STS スペクトルでは，バックボンドのピーク が消失しており, バックボンドに窒素が吸着して電子状態が 変化したものと考えられる. 以上のように, 窒素ラジカルを 用いた $\mathrm{Si}(001)$ 基板表面の窒化初期過程では，C型欠陥やダ イマー欠損列などの生成を伴いつつ，バックボンドへの窒素 の吸着によって窒化がく110〉方向に進行する.

\section{4. シリコン窒化表面における表面ラフネスおよ びエネルギーバンドギャップのプロセス温度 依存性 ${ }^{15)}$}

Fig. 9 は基板温度（a）350，(b) 600，(c）650および（d） $700^{\circ} \mathrm{C}$ でラジカル窒化した $\mathrm{Si}(001)$ 表面の STM 像である. ラ ジカル窒化時の RF 電力は $200 \mathrm{~W}$ であった。 オージェ電子 分光 (AES) 法より, 膜厚方向に一様な組成であるとして
求めた $\mathrm{Si}$ 窒化膜の膜厚はそれぞれ（a） 0.56，(b) 0.72，(c) 0.67 およひ（d） $0.90 \mathrm{~nm}$ であった. STM 観察時の試料バイ アスは+2.0 V である. 基板温度 $600^{\circ} \mathrm{C}$ 以下でラジカル窒化 した場合には， $\mathrm{Si}(001)$ 表面に由来するシングルステップ構 造が確認され，シリコン窒化膜が層状成長していることがわ かる. 一方, 基板温度 $650^{\circ} \mathrm{C}$ 以上でラジカル窒化した場合に は，ステップ構造は観察されない。高温では $\mathrm{Si}$ 基板表面で の $\mathrm{Si}$ 原子の表面泳動（マイグレーション）が活発となるた めに，シリコン窒化膜が島状成長したものと考えられる.

Fig. 10は, ラジカル窒化後の Si 基板表面の STM 像から 求めた平均二乗 (RMS) 粗さである. 基板温度 $650^{\circ} \mathrm{C}$ 以上に おいて RMS 粗さが顕著に増大しており，シリコン窒化膜が 島状成長することによって表面ラフネスが増大することがわ かる. 一方, RMS 粗さの RF 電力に対する依存性はほとん ど見られない。すなわち, ラジカル窒化法における $\mathrm{Si}$ 窒化 膜の成長様式は，窒化種には依存せず， $600^{\circ} \mathrm{C}$ 以下で層状な 成長が起こることを示している。

Fig. 11は，基板温度 $350^{\circ} \mathrm{C}$ および $750^{\circ} \mathrm{C}$ で成長した $\mathrm{Si}$ 窒化 膜におけるSTS スペクトルである. 比較として， $\mathrm{Si}(001)$ 清 浄表面に抢けるSTS スペクトルも示している. ラジカル窒
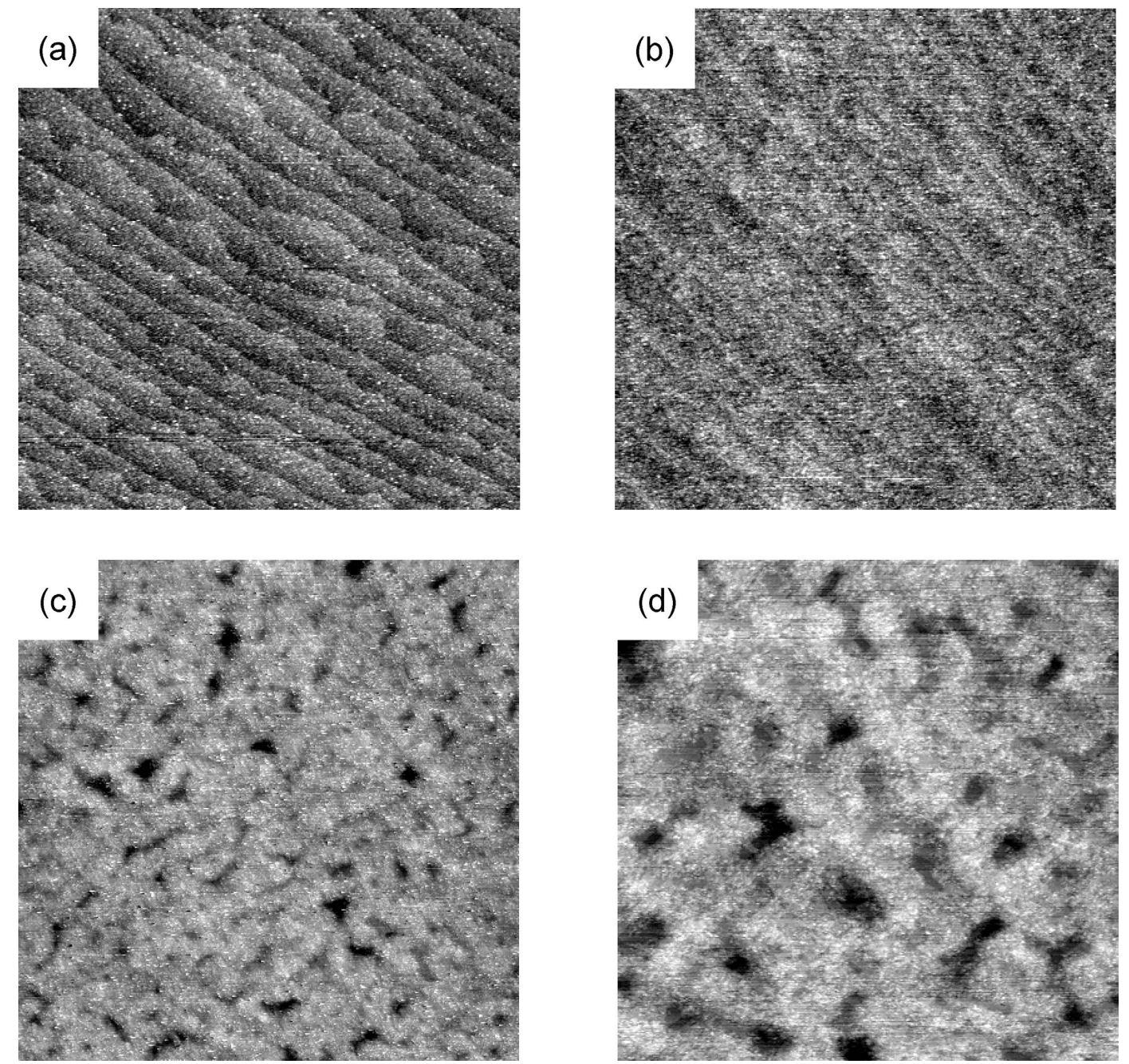

Fig. 9 STM images of silicon nitride layers formed at temperatures of (a) 350 , (b) 600 , (c) 650 , and (d) $700^{\circ} \mathrm{C}$. RF power was $200 \mathrm{~W}$. The thicknesses of the nitride layers were (a) 0.56 , (b) 0.72 , (c) 0.67 , and (d) $0.90 \mathrm{~nm}$, respectively. All STM observations were performed at a sample bias of $+2.0 \mathrm{~V}$. The scan area was $500 \times 500 \mathrm{~nm}^{2}$. 


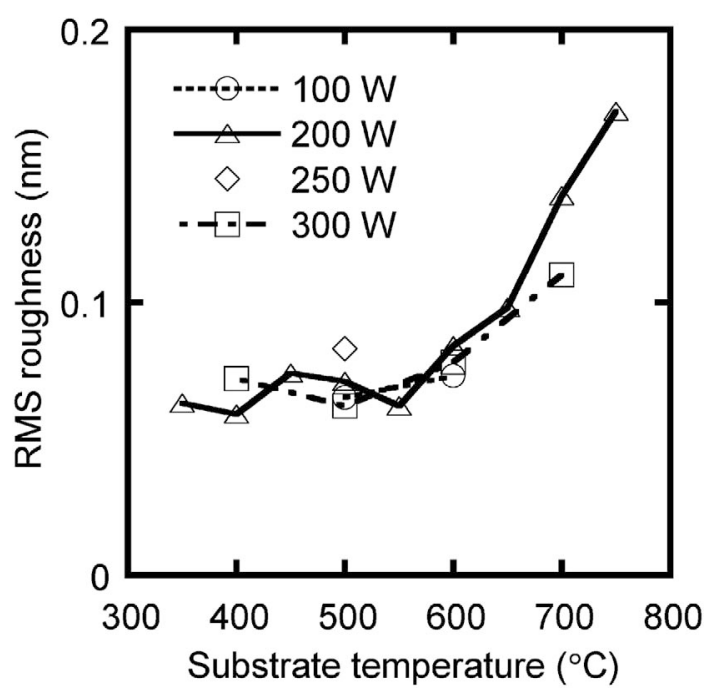

Fig. 10 RMS roughness of the silicon nitride layers as a function of substrate temperature during the radical nitridarion.

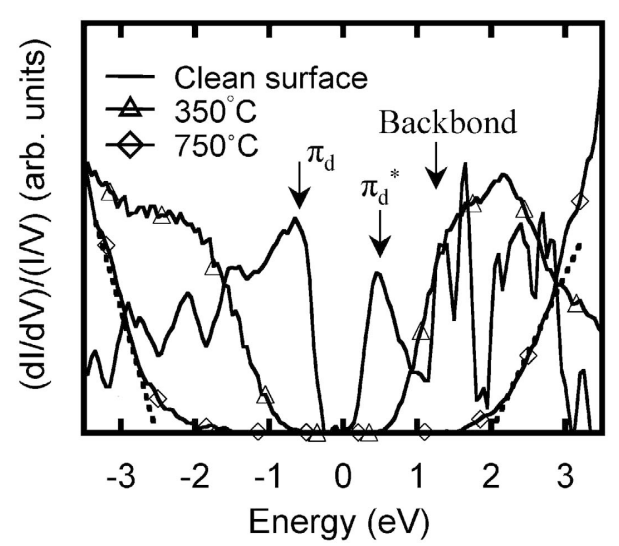

Fig. 11 STS spectra of the $\mathrm{Si}(001)$ clean surface and silicon nitride layers formed at temperatures of $350^{\circ} \mathrm{C}$ and $750^{\circ} \mathrm{C}$.

化時の RF 電力は $200 \mathrm{~W}$ であった. $\mathrm{Si}(001)$ 清浄表面のスペ クトルに対し，ラジカル窒化後のスペクトルでは $\pi_{\mathrm{d}}$ 結合状 態, $\pi_{\mathrm{d}}^{*}$ 反結合状態抢よびバックボンドに起因するピークが 観測されない，また窒化後では，フェルミレベル（図中原点） 付近のエネルギーバンドギャップ $\left(\mathrm{E}_{\mathrm{g}}\right)$ が増大しており， シリコン窒化膜が形成したことがわかる.

Fig. 12はSTS スペクトルから求めた Si 窒化膜の $\mathrm{E}_{\mathrm{g}}$ であ る. 横軸はラジカル窒化時の基板温度である. $\mathrm{RF}$ 電力 200 $\mathrm{W}$ 以下では，基板温度の上昇と共に $\mathrm{E}_{\mathrm{g}}$ が大きくなり，600 ${ }^{\circ} \mathrm{C}$ 以上に扔いて $\mathrm{E}_{\mathrm{g}}$ はほぼ一定となり，Si 窒化膜バルクの報 告值に近い約 $4.4 \mathrm{eV}$ が得られている. 一方, 基板温度 $500^{\circ} \mathrm{C}$ 以下では, $\mathrm{RF}$ 電力が大きいほど $\mathrm{E}_{\mathrm{g}}$ が大きくなる傾向があ り, $\mathrm{RF}$ 電力 $300 \mathrm{~W}$ では, $600^{\circ} \mathrm{C}$ 以下でも $3.6-3.8 \mathrm{eV}$ と比較 的大きな $\mathrm{E}_{\mathrm{g}}$ が得られている.これらの結果は, ラジカル窒 化法に打ける $\mathrm{Si}$ 窒化膜のエネルギーバンドギャップ形成 が，基板温度のみならず反応種の密度や種類にも依存するこ とを示している.

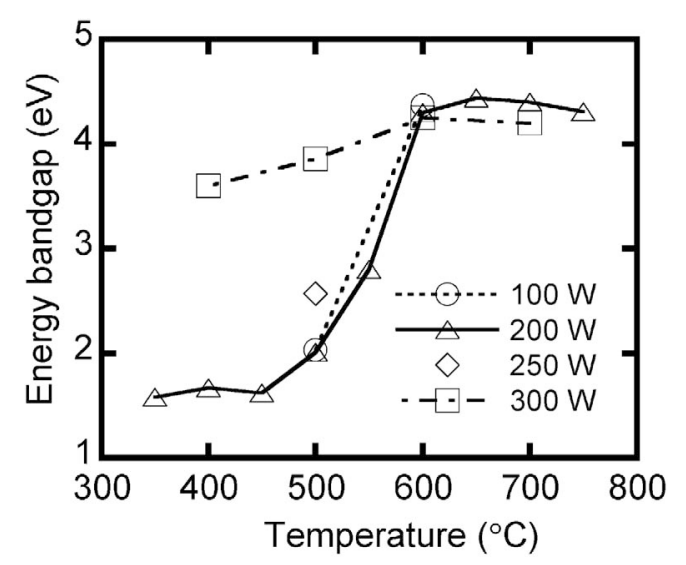

Fig. 12 Temperature dependence of energy bandgap of the silicon nitride layers obtained from the STS spectra. RF powers at the radical nitridation were 100 to $300 \mathrm{~W}$.

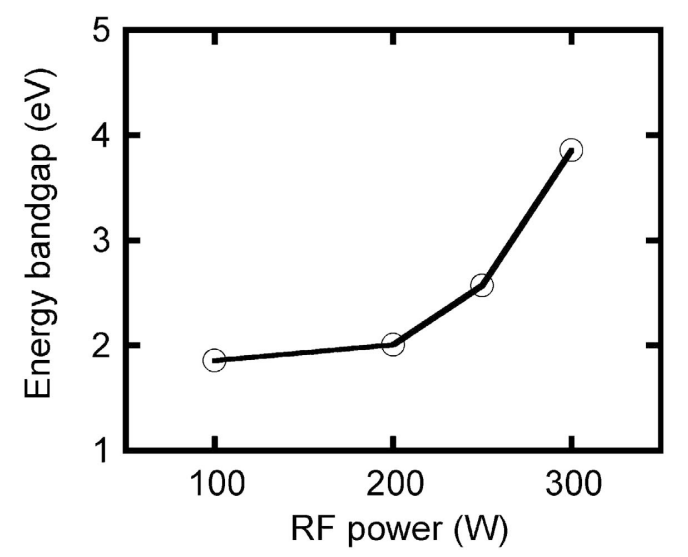

Fig. 13 RF power dependence of energy bandgap of the silicon nitride layers formed by the radical nitridation at a temperature of $500^{\circ} \mathrm{C}$.

\section{5. ラジカル窒化過程における反応種依存性 ${ }^{15)}$}

Fig. 13は，基板温度 $500^{\circ} \mathrm{C}$ でラジカル窒化した場合におけ る $\mathrm{Si}$ 窒化膜の $\mathrm{E}_{\mathrm{g}}$ の $\mathrm{RF}$ 電力依存性である. $\mathrm{RF}$ 電力が大き いほど $\mathrm{E}_{\mathrm{g}}$ が大きくなっており，特に $\mathrm{RF}$ 電力 $250 \mathrm{~W}$ から $300 \mathrm{~W}$ では $\mathrm{E}_{\mathrm{g}}$ が䫓著に増大している，第 2 節で述べたよう に, $\mathrm{RF}$ 電力 $250 \mathrm{~W}$ から $300 \mathrm{~W}$ の領域では, ICP 中の $\mathrm{N}$ の 絶対密度はあまり変化しない。 また発光スペクトルに执てて, $\mathrm{N}_{2}^{*}$ に起因するピーク強度も飽和傾向にあり, $\mathrm{N}_{2}^{*}$ の密度変化 も小さいと考えられる.これらに対し， $N^{*} に$ 起因する発光 スペクトルは RF 電力 $250 \mathrm{~W}$ から $300 \mathrm{~W}$ の領域に扔いて増 大しており, $\mathrm{N}^{*}$ の寄与の增大によりシリコン窒化膜のエネ ルギーバンドギャップ形成が促進されたことが考えられる.

\section{6. シリコン表面のラジカル窒化過程におけるエ ネルギーバンドギャップ形成 ${ }^{15}$}

Fig. 14はラジカル窒化によって作製した $\mathrm{Si}$ 窒化膜に扔け る二乗平均粗さとエネルギーバンドギャップの温度依存性で ある. 窒化時の $\mathrm{N}_{2}$ 分圧は $2.7 \times 10^{-3} \mathrm{~Pa}$ である. 様々な温度 および RF 電力でラジカル窒化を行った結果であるが, 窒化 時間の制御によって何れの場合も膜厚 $0.6-0.9 \mathrm{~nm}$ 程度の $\mathrm{Si}$ 


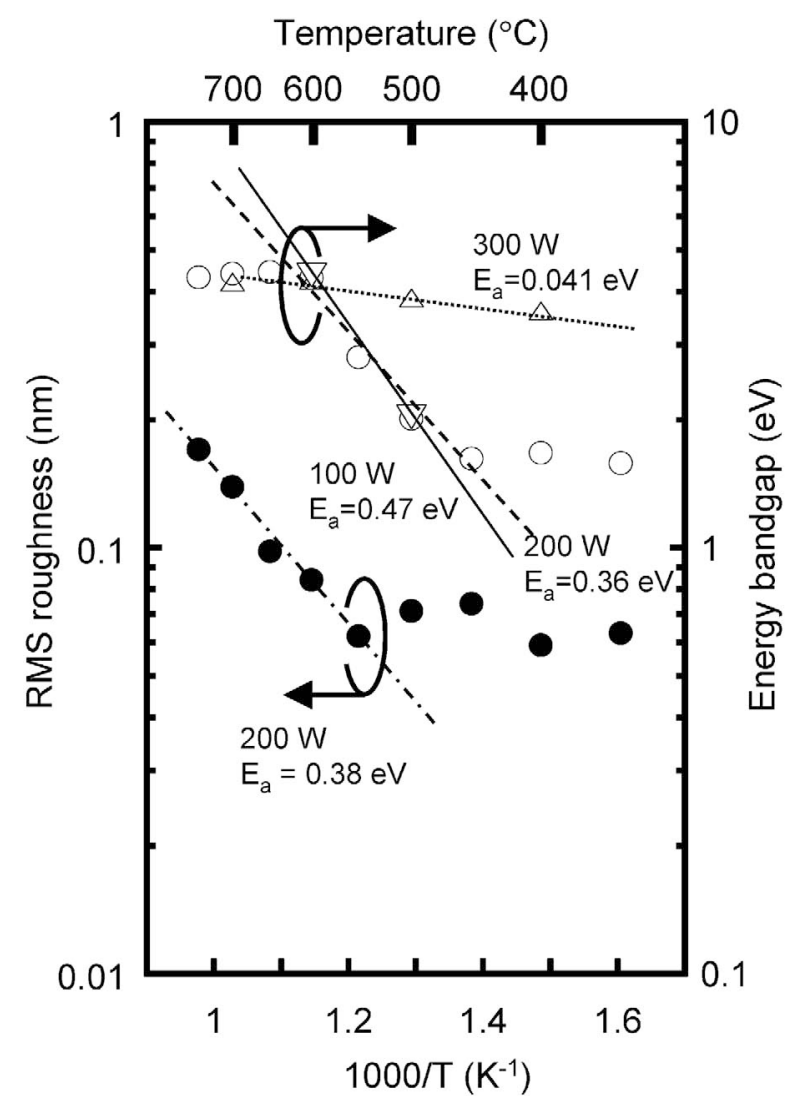

Fig. 14 Temperature dependence of RMS roughness (closed circles) and energy bandgap (opened marks) of the silicon nitride layers formed by radical nitridation.

窒化膜が形成されていることを AES 法により確認してい る. 一方, Si と窒素の AES スペクトルのピーク強度比は, いずれの Si 窒化膜に抢いても同程度であり, 窒化条件に依 存した元素組成比の変化はほとんど無いものと考えられる. 第 4 節に抢いても述べたように, 窒化時の基板温度 $650^{\circ} \mathrm{C}$ 以 上では, $\mathrm{Si}$ 原子の表面泳動の活性化によって $\mathrm{Si}$ 窒化膜が島 状成長し, 基板温度の増大に伴って表面粗さが増大する. Fig. 14 より, RMS 粗さの活性化エネルギーは $0.38 \mathrm{eV}$ と得 られた。な抢，RMS 粗さについては RF 電力 $200 \mathrm{~W}$ の場合 の反を示しているが，ラジカル窒化に抢けるSi窒化膜の成長 様式抢よび表面粗さは基板温度の久に依存し， RF 電力に依 存しない. $\mathrm{Si}(001)$ 表面に抢ける $\mathrm{Si}$ 原子の泳動の活性エネル ギーは $0.7 \mathrm{eV}$ と報告されており, 同程度の值となっている. RMS 粗さの活性化エネルギーと Si 原子の表面泳動の活性化 エネルギーとを単純には結び付けることは出来ないが, 表面 泳動が $\mathrm{Si}$ 窒化膜の成長様式を律速する要因であることを示 唆するものと考元られる。一方，エネルギーバンドギャップ の活性化エネルギーは RF 電力 100,200 抢よび $300 \mathrm{~W}$ に対し てそれぞれ $0.47,0.36$ 打よび $0.041 \mathrm{eV}$ と得られた。 この活性 化エネルギーの起源は明らかでないが， Nに比べ内部エネ ルギーが大きい $\mathrm{N}^{*}$ の寄与が大きくなることにより, $\mathrm{Si}-\mathrm{N}$ 結 合の形成過程における基板温度依存性が小さくなったものと 考えられる。いずれにしても，この結果は， $600^{\circ} \mathrm{C}$ 以下でも プラズマ条件（反応種）を制御することによって均一で膜質 の良いシリコン窒化膜を形成可能であることを示している.

\section{7. まと め}

ラジカル窒化法による $\mathrm{Si}$ 基板表面の窒化機構について, 窒素プラズマ中の窒素ラジカル分析 (手法抢よび分析結果), 窒化初期過程の原子レベル構造解析, そして STS スペクト ルに基づいた $\mathrm{E}_{\mathrm{g}}$ 形成過程に関する考察を述べた。窒化初期 課程では, $\mathrm{Si}(001)$ 表面にダイマー欠損列や C 型欠陥などの 欠陥形成を伴う。これは酸化初期過程には見られない, 窒化 過程特有の現象である. ラジカル窒化による $\mathrm{Si}$ 窒化膜の成 長様式は, 主に基板温度に依存する。 それに対し， Si 窒化 膜の $\mathrm{E}_{\mathrm{g}}$ 形成は基板温度と窒化種の両方に依存して変化す る。基板温度が大きいほど, $\mathrm{E}_{\mathrm{g}}$ は増大し, 基板温度 $600^{\circ} \mathrm{C}$ 以 上で，バルクの $\mathrm{Si}$ 窒化膜に近い $4.4 \mathrm{eV}$ 程度に達する. 一方, $600^{\circ} \mathrm{C}$ 未満の低温であっても， $\mathrm{N} *$ の寄与の大きい窒化条件を 用いることで, 大きな $\mathrm{E}_{\mathrm{g}}$ を持つ $\mathrm{Si}$ 窒化膜が形成可能と考え られる. ラジカル窒化は様々な窒素ラジカルやイオンが寄与 する複雑な現象であるが, 高誘電率 (High-k) ゲート絶縁 膜の導入なぞに伴い，今後ますます原子レベルでの窒化機構 の理解と制御の重要性が高まることと考えられる. 本稿で述 べたように，VUVASやOESなどのプラズマ分析を活用す ることで, 次世代 ULSI 技術における精密制御されたプラズ マプロセスの発展が期待される.

\section{謝辞}

本稿は主に, 名古屋大学大学院工学研究科安田研究室なら びに財満研究室に扔いて実施された研究の成果を纏めたもの である. 研究実施時から現在に至るまで, 多くのご助言をい ただいた安田幸夫先生（現, 高知工科大学教授）に心から感 謝いたします。

\section{〔文献〕}

1) F. K. Baker, J. K. Pfiester, T. C. Mele, H-H. Tseng, P. J. Tobin, J. D. Hayden, C. D. Gunderson and L. C. Panillo: IEDM Tech. Dig., pp. 443-446 (1989).

2) T. Morimoto, H. S. Momose, Y. Ozawa, K. Yamabe and H. Iwai: IEDM Tech. Dig., pp. 429-432 (1990).

3) G. Lo and D.-L. Kwang: IEEE Electron Device Lett., 12, pp. 175-177 (1991).

4) N. Kimizuka, K. Yamaguchi, K. Imai, T. Iizuka, C. T. Liu, R. C. Keller and T. Horiuchi: Symp. on VLSI Tech., p. 92-93 (2000).

5) Z. Wang, C. G. Parker, D. W. Hodge, R. T. Croswell, Nian Yang, V. Misra and J. R. Hauser: IEEE Electron Device Lett., 21, p. 170-172 (2000).

6) K. K. Abdelghafar, K. Watanabe, J. Ushio and E. Murakami: Appl. Phys. Lett., 81, pp. 4362-4364 (2002).

7) S. Fujieda, Y. Miura, M. Saitoh, E. Hasegawa, S. Koyama and K. Ando: Appl. Phys. Lett., 82, pp. 3677-3679 (2003).

8) T. Hori, H. Iwasaki, Y. Yoshioka and M. Sato: Appl. Phys. Lett., 52, pp. 736-738 (1988).

9) J. W. Kim, H. W. Yeom, Y. D. Chung, K. Jeong, C. N. Whang, M. K. Lee and H. J. Shin: Phys. Rev. B, 66, pp. 035312-035315 (2002).

10) F. Monforte, M. Camalleri, D. Cali, G. Curro, E. Fazio and F. Neri: Microelectronics Reliability, 47, pp. 822-824 (2007).

11) N. Miyata, H. Watanabe and M. Ichikawa: Appl. Phys. Lett., 76, pp. 3561-3563 (2000).

12) H. Hwang, W. Ting, D. L. Kwong and J. Lee: Appl. Phys. 
Lett., 57, 1010-1011 (1990).

13) H. C. Lu, E. P. Gusev, T. Gustafsson, E. Garfunkel, M. L. Green, D. Brasen and L. C. Feldman: Appl. Phys. Lett., 69, 27132715 (1996).

14) D. Matsushita, K. Muraoka, K. Kato, Y. Nakasaki, S. Inumiya, K. Eguchi and M. Takayanagi: Microelectronic Engineering, 80, pp. 424-431 (2005).

15) H. Kondo, K. Kawaai, A. Sakai, M. Hori, S. Zaima and Y. Yasuda: Jpn. J. Appl. Phys., 46, pp. 71-75 (2007).

16) S. Takashima, S. Arai, M. Hori and T. Goto: J. Vac. Sci. Technol., A 19, pp. 599-602 (2001).

17) D. Matsushita, H. Ikeda, A. Sakai, S. Zaima and Y. Yasuda: Thin Solid Films, 369, pp. 293- 296 (2000).
18) D. Matsushita, H. Ikeda, A. Sakai, S. Zaima and Y. Yasuda: Jpn. J. Appl. Phys., 40, pp. 2827-2829 (2001).

19) H. Ikeda, D. Matsushita, S. Naito, K. Ohmori, A. Sakai, S. Zaima and Y. Yasuda: Jpn. J. Appl. Phys., 41, pp. 2463-2467 (2002).

20) T. Uda and K. Terakura: Phys. Rev. B, 53, pp. 6999-7001 (1996).

21) J. A. Appelbaum, G. A. Baraff and D. R. Hamann: Phy. Rev. B, 14 , pp. 588-601 (1976).

22) R. J. Hamers and U. K. Kohler: J. Vac. Sci. \& Technol., A 7, pp. 2854-2859 (1989).

23) R. M. Feenstra, J. A. Stroscio and A. P. Fein: Surf. Sci., 181, pp. 295-306 (1987). 